outbreak of War, upper air observations were not available, and if they had been forecasters would not have known what to do with them. The conditions are very different now; for aeroplanes have made it possible to get the information quickly, and our new knowledge of the part played by air masses and surfaces of discontinuity makes all information from the upper air of great importance. Practically all countries now use aeroplanes for upper air observations as part of their forecasting services.

There can be no doubt that during the last twenty-five years the forecaster has made great steps forward and forecasting is slowly being changed from an art, in which experience and intuition played the predominating part, into a science in which cause and effect are recognised and taken into account.

\title{
Conceptions of Man's Ancestry
}

\section{By Sir Arthur Keith, F.R.s., lately Hunterian Professor of the Royal College of Surgeons}

$\mathrm{W}$ HEN King George came to the throne, anthropologists had begun to realise that man's family tree was to prove a much more complicated thing than was anticipated. The discoveries made in France between 1907 and 1909 compelled them to abandon the idea that mankind had been evolved by a single progressive series of stages which, beginning in an ape-like stage, ended in the races of modern humanity. They had to give up the singlestemmed family tree and substitute for it one with rather a shrub-like outline. Most of them regarded Neanderthal man as a stage in the evolution of modern man. The discoveries made in France, at the date just mentioned, proved that this could not be so, and that Neanderthal man, after occupying Europe for a large part of the pleistocene period, had been suddenly replaced by representatives of modern or neanthropic man. Whether the neanthropic races, which replaced the Neanderthal inhabitants of Europe, came from Africa or from Asia still awaits determination. Neanderthal man could not be fitted into any single-stemmed scheme; he represented the end twig of a dead branch. Since 1910, several more dead branches have been discovered and fitted into provisional reconstructions of man's family tree.

At the beginning of this period another idea relating to the antiquity of modern man was being much discussed. Was it possible that human beings, exactly similar to modern Europeans in details of structure, could have been in existence in mid-pleistocene times, when the $100 \mathrm{ft}$. terrace of the Thames was being laid down and the large Chelles hand-axes were being fashioned? There were many-including the writer-who answered this question in the affirmative. The case we relied on was that of Galley Hill, near Gravesend, but discoveries of a similar kind had also been reported from France, from Italy and from North America. Galley Hill man lay under mid-pleistocene strata which were apparently unbroken. The discoveries which have been made during the past twenty-five years have not supported the Galley Hillites; the opposite has been the case. Most anthropologists now hold that the human body is so unstable in its constitution-and always has been so unstable-that it cannot continue the same over a long period of time, but must change. Hence we are all inclined now, in the case of Galley Hill and all discoveries of a similar kind, to reject the geological evidence rather than believe that the human body can exist for a long period of time-say, 50,000 years-and remain unchanged.

Our knowledge of Neanderthal man has been greatly extended. In 1911 Marcelin Boule pub. lished his classical monograph on the anatomy of La Chapelle man-perhaps the best known of Neanderthal specimens. The earliest or oldest trace of the Neanderthal phylum is represented by the Heidelberg mandible, which was discovered in 1907. In spite of a prolonged search, this is still the sole trace we have of the ancestry of Neanderthal man in the earlier part of the pleistocene period. Two discoveries, however, have revealed stages which fill up in some degree the interval between the early Heidelberg and late La Chapelle stages in the evolution of the Neanderthal type. One of these was made in the travertine quarry at Ehringsdorf, near Weimar, in 1925 ; the other was made in a gravel pit, just outside Rome, in 1929. At Ehringsdorf and at Rome, the Neanderthal skulls were embedded in deposits formed during the long temperate interval which preceded the last glacial period. The Ehringsdorf man was big-brained and had certain characters more reminiscent of modern (neanthropic) man than the later Neanderthal specimens. There are reasons for linking the discovery at Ehringsdorf with that made at Krapina, Croatia, in 1906. A discovery made in 1924 revealed the fossil remains of Neanderthal man in the Crimea, thus carrying the distribution of this extinct type almost into Asia. 
One very strange fact is that not a fossil bone of Neanderthal man has been found in England. Traces of his body were found in Jersey by Dr. R. R. Marett in 1911, and they have been found abundantly in France and in Belgium. Yet the work-floors of Neanderthal man abound in the south-eastern parts of England. Fossil remains of neanthropic man (Homo sapiens) have never been found in or under an intact stratum containing the stone implements of Neanderthal manimplements of the Mousterian culture. This culture has always been found in association with Neanderthal man.

The most remarkable and the most unexpected discovery of ancient man recorded in the period under review was made at Piltdown. Sussex, in the opening years of the King's reign. Eager search over a long period had brought to light human remains in many parts of England, but always they were of the present-day type. English anthropologists had come to believe that the first and only inhabitants of England were men of the modern type, when to the surprise of everyone the late Mr. Charles Dawson and Sir Arthur Smith Woodward produced Piltdown man-the most remarkable form of extinct humanity which has been discovered in any part of the world. The criticism which this discovery has met with, ever since its first announcement, has in no wise detracted from its authenticity or its importance. Piltdown revealed the fact that, at the beginning of the pleistocene period, England was the home of men who had in their structure a mixture of parts-most of them modern yet some strange, such as those of the forehead, and some ape-like, such as those of the lower jaw. Indeed, the Pilt. down lower jaw has been assigned by quite competent zoologists to an extinct kind of chimpanzee. Sir Arthur Smith Woodward found small fragments of other individuals at Piltdown, but so far no other traces of this early type of man has been discovered in England or elsewhere in Europe. It is usually held that Piltdown man (Eoanthropus) represents a form of humanity which died out early in the pleistocene period. This, however, is a view which is not held so firmly now as it was formerly.

Another type of humanity in early England, authentic in all details relating to its discovery, came to light when foundations were dug for Lloyd's Buildings in the city of London in 1925. The London skull, which was found then, occurred under a stratum laid down in mid-pleistocene times. This places the ancient Londoner well within the period when the inhabitants of Europe were Neanderthalians. Although the London skull is incomplete, yet there is enough of it to justify the exclusion of its owner from the Nean- derthal category. The London skull is essentially modern in character, but in the opinion of the writer it does show features which suggest a relationship to the Piltdown type. Only further discovery can determine the significance of the London skull and its place in the evolutionary family tree.

Although only a single sperimen of the humanity which occupied England at the beginning of the pleistocene period has been discovered, yet there is abundant evidence that England was a home for evolving mankind as early as the pliocene period. Just before 1910, Mr. Reid Moir announced the existence of humanly worked implements in the sub-crag beds of East Anglia. $\mathrm{He}$ has added to his evidence in every one of the twentyfive years which have elapsed since 1910, and now distinguishes at least three distinct stone cultures under the Red Crag of Suffolk.

In 1925, students of fossil man had their attention directed to Palestine by a discovery made near Lake Galilee by Mr. Turville Petre. Deep in the floor of a cave, rich with stone implements of the Mousterian culture, he found part of a skull, which although Neanderthal in its main characters, yet had certain features which were of a different nature. Between 1929 and 1933, Miss Dorothy Garrod, working for the British School of Archæology in Jerusalem, explored the caves of Mount Carmel, and found them laden with human relics of the pleistocene period. In one cave Miss Garrod explored and examined a continuous series of superimposed strata $52 \mathrm{ft}$. in thickness- the most extensive and richest cave deposit known to us. The strata covered the period in which Europe was inhabited by Neanderthal man. Altogether, remains of about fifteen individuals were found in the Carmel caves, six of which represent approximately complete skeletons. The fossil remains of ten individuals lay in the smallest of the Carmel caves which was excavated by Mr. Theodore McCown. All the fossil remains from the Mousterian deposits of Mount Carmel are of the Neanderthal type, but like the Galilean specimen, show many strange features in some of which they approach the modern type of mankind. Thus we now know that for a very considerable part of the pleistocene periodroughly its middle third-Palestine was inhabited by a strange breed of Neanderthal man, some of them very tall and massively built. As in Europe, the Neanderthal race was suddenly replaced by men of the modern type at the end of the Mousterian phase of culture. The present belief is that these ancient Palestinians represent an extinct people.

Almost at the same time as Palestine, China claimed the attention of students of prehistoric 
man. By a series of isolated discoveries, it became known that the limestone hills at Chou-Kou-Tien, 37 miles from Peping, contained a vast cave packed with remains of the pleistocene period. Most of the contents of the cave had been brought within the cave very early in the pleistocene period. The oldest cave strata were found to contain crude stone implements, fossil remains of human beings and of hearths. The fossil remains were found to represent a primitive form of humanity which Prof. Davidson Black namedSinanthropus. Sinanthropus is certainly one of the oldest and lowest forms of humanity known to us. His exact position in the family tree which represents the evolution of humanity is still uncertain. Prof. Davidson Black, who was cut off by death at forty-nine years of age in March 1934, was the man, above all others, who was best qualified to solve the enigmatic position of Peking man. $\mathrm{He}$ died at Peping in the midst of his labours. It may be that this ancient fossil type, so unlike any of the modern Mongolian peoples, may nevertheless prove to be on the line of Mongolian descent, for there are now grounds for believing that the chief races of mankind have been evolved in the continents they now inhabit.

When the British Association met in Australia in the autumn of 1914 , there was submitted to it a fossil human skull, known as the Talgai skull. It had been derived from a pleistocene deposit in Queensland, and was marked by the cranial characters of the Australian aborigine, save that the jaws were more robust than is usual in the modern native and the brain was rather larger. The Talgai skull, which was described by Dr. S. A. Smith in 1918, is the earliest representation. of the Australian aborigine known to us.

The publication of Dr. S. A. Smith's monograph led Prof. Eugene Dubois of Leyden to divulge a secret he had kept ever since 1891-92, when he was in Java and discovered the fossil remains of Pithecanthropus erectus. He revealed the fact that he not only found these famous fossils, which came from very early pleistocene deposits-if not late pliocene-but also in deposits of late pleistocene date, two other fossil skulls. These two specimens, known as the Wadjak skulls, like that of Talgai, had large jaws and also a great brain space. Prof. Dubois recognised that the Wadjak skulls had Australian affinities. At first there was no suspicion of a direct relationship between the small-brained and lowly-placed Pithecanthropus and the largebrained Wadjak man. A discovery made by officers of the Geological Survey of Java makes it possible to believe that Pithecanthropus may be the ancestor of the Wadjak man, for the Solo skull, discovered in 1932 , is intermediate to the other two skulls in many respects. It is intermediate in time and it is also intermediate in brain development. We cannot assert as yet that the Australian aborigines have been evolved from a pithecanthropoid ancestor, but with the Solo, Wadjak and Talgai discoveries providing a series of rising evolutionary steps, we have now to consider seriously the possibility of such an origin for the Australian aborigine. We have also to face the possibility of a separate or parallel evolution of various races of modern humanity. Modern races may have come by their neanthropic characters independently of one another.

In recent years, Africa has been providing evidence which raises a similar suspicion regarding the evolution of African races. In 1913 there were discovered at Boskop, in the Transvaal, fossil remains of a big-brained specimen of humanity. At first there was no evidence of its exact date, but now there are grounds for attributing it to a late phase of the pleistocene period. The Boskop type, with a strikingly large brain and relatively small jaws, proved to be the forerunner of the Strandloopers of South Africa. The Bushman type was also an inhabitant of South Africa in the later part of the pleistocene period as was proved in 1927 by the discovery of an ancestral form made by the Messrs. Peers in the Fish Hoek Cave, in the Cape Peninsula. The modern Bushman has not the size of brain or strength of jaw of his fossil ancestor. The Boskop and Bushman are cousin types, and we may hope to find their common ancestor.

Thus in later pleistocene times, Africa south of the Zambezi was the home of nearly related races, big in brain but short in stature. At a much earlier period-perhaps as far back as the pliocene period, this part of Africa was the home of a remarkable anthropoid ape-one which made a nearer approach to man than either the chimpanzee or gorilla. The existence of this remarkable apeAustralopithecus it was named by Prof. Raymond Dart—was made known by the discovery in 1924 of a fossilised skull of a young individual in a limestone quarry at Taungs in the Harts River Valley some eighty miles from Kimberley. The varying opinions formed by experts as to the significance of the Taungs discovery will be found in the columns of NATURE from 1925 onwards. Indeed every discovery of ancient man made in recent years has found a full record in these pages.

When we move to Africa north of the Zambezi, we enter another territory of human evolution. Deep in the mine at Broken Hill, Northern Rhodesia, a remarkable fossil type of man came to light in 1921. The fossil type thus discovered is one of the most primitive forms of humanity known to us. In his structural composition, Rhodesian man displays everything that we expect 
in an early stage of the evolution of modern man (Homo sapiens). Unfortunately, there was nothing found with the bones of Rhodesian man which tells us at what point in the pleistocene period he lived; we infer from the circumstances in which he was found that he is at least mid-pleistocene in date. Some light has been thrown on this and other problems relating to the history of early man in Africa by Dr. Louis Leakey's researches. Dr. Leakey led three expeditions to East Africa between 1925 and 1932, in the course of which he demonstrated the existence of implement-containing deposits covering the greater part of the pleistocene period. Near the base of these deposits was discovered a fragment of a human lower jaw -which has characters not unlike those we expect to find in Rhodesian man. In strata of later but of uncertain date at Kanjera, Dr. Leakey found cranial fragments of the most primitive type of Negro known to us. At first sight, the difference between the Rhodesian and Kanjera types of humanity seems very great, and yet in the opinion of the writer it is possible to conceive the evolution of the Kanjera Negro from Rhodesian man. Whether this evolution has taken place or not is one of the many problems which students of fossil man may hope to solve in the near future.

When King George came to the throne our knowledge of ancient man was almost entirely confined to Europe. Java was the only exception. Discoveries of fossil man of extinct types have now been made in every continent of the world. Every large land area-Europe, Asia, Africa and Australasia-has yielded fossil remains of human types totally different from any now living-all save America. No evidence has been found of the existence in the New World of a type of humanity that differs materially from types which still exist in America.

\section{Discovery and Significance of Vitamins}

\section{By 'Sir Frederick Gowland Hopkins, P.R.s., Sir William Dunn Professor of Biochemistry, University of Cambridge}

UNTIL the end of the first decade of the present century, official teaching concerning the nutritional needs of the human body was still based on the results of classical studies by Carl Voit and Max Rubner and on the views of the Munich School thence derived. The adequacy of a dietary was measured in terms of calories and protein alone. It was generally believed, alike by the academic physiologist and by those concerned with practical dietaries, that, questions of palatability and digestibility apart, so long as the food of an individual provided sufficient potential energy for the activities of his internal organs and for the external mechanical work he might be called upon to do, the only demand of a more specific kind made by his body was for a certain, rather ill-defined, minimum of protein, to subserve the growth and maintenance of its tissues. Beside the carbohydrates, fats and proteins which provide these essentials, natural foods were known, of course, to contain a variety of other substances. These, however, are present individually in very small amount, and except for certain minerals among them, necessary for the formation of bone and for the maintenance of particular physical conditions in the body, they assumed to be without nutritional importance.

Facts, nevertheless, were already known which might well have suggested that the body makes calls upon its food to supply needs more subtle and more specific than those thus recognised. The history of scurvy, for example, and the clear demonstration, made already in the eighteenth century, of the dramatic cure of that fell disease which follows upon suitable, though relatively very small, additions to an errant dietary, should, it would seem, have provided a strong suggestion for the existence in certain foods of a substance small in amount but with highly specific properties essential for the support of normal nutrition; that is, for the existence of what we now define as a vitamin. But unfortunately, the views of the majority concerning the influence of anti-scorbutic foods remained for many years vague and obscure. It was attributed to such qualities as 'freshness' without further analysis of these qualities, or to known constituents without proof of their efficacy. True, so far back as 1841, an American physician, G. Budd, had ascribed the action of such foods "to an essential element which it is hardly too sanguine to state will be discovered by organic chemistry or the experiments of physiologists in a not far distant future". Had organic chemists or physiologists been then stimulated by this objective view to seek for a definite substance in such well-known anti-scorbutic materials as, say, lemon or orange juice-a substance which when isolated could display by itself the anti-scorbutic powers of these fruits-it is likely that a realisation of the significance of vitamins might have come 